\title{
Gender Gap in German Management Positions and Recommendations for Equality
}

\author{
Ilham Bekdemir \\ Faculty of Business Administration and Economics \\ Bielefeld University, Germany \\ Margarita Ackermann \\ Schumpeter School of Business and Economics \\ University of Wuppertal, Germany \\ Larissa Beil \\ Schumpeter School of Business and Economics \\ University of Wuppertal, Germany \\ Nils Cröger \\ Faculty of Business and Economics \\ Anhalt University of Applied Sciences, Germany \\ Bahaudin G. Mujtaba \\ The H. Wayne Huizenga School of Business and Entrepreneurship \\ Nova Southeastern University
}

\begin{abstract}
Companies depend on highly qualified executives to survive and to keep up with the increasing global competition. Modern and globally dynamic companies often get criticized for the underrepresentation of women in management and senior level executive positions. These globally dynamic understand that they cannot do without the capability and commitment of qualified women to be successful in the future. Furthermore it has been proven that mixed teams of women and men work more efficiently, their capability grows faster, and they earn higher profits in comparison to homogeneous teams. Nevertheless, in many companies gender discrimination is a daily life. The result of this is an unequal allocation of gender gap in management positions favouring men. This article explores some of the reasons for the gender gap problem and how it can be solved. The authors provide suggestions to solve the dilemma and to overcome certain circumstances of mentality patterns in the organization's culture.
\end{abstract}

Key Words: Gender, discrimination, glass ceiling, stereotypes, Germany, Norway.

\section{INTRODUCTION}

Ermaine de Stael has been quoted as having said that "success has no gender", yet modern females face more barriers than their male counterparts in reaching the upper levels of management. In other words, there is no equality in management opportunities among males and females, since men tend to get promoted faster into managerial and senior level positions. There is a great need for fairness and equality in promotions and management opportunities for females working in the modern workplace (Mujtaba, 2014). Workplace equality should lead to an overall improvement in the quality of life of all people, because it reduces poverty, improves education, and increases the economic growth (Harter, Schmidt \& Keyes, 2002). The 
equality between men and women is a human right afforded to everyone. Worldwide females assume many responsibilities in the workplace but their performance is often not appreciated. They are often disadvantaged and discriminated against. In comparison to men, most females do the largest part of the job or equal to men but they earn around twenty percent less income. Even in the political and business environments women are not equal in comparison with men. The economic potential and performance of women are widely undervalued and therefore often unused. In the German economy women are underrepresented in the highest leadership positions (Reimann, 2012; Hofmeister and Hünefeld, 2010).

Next to reasons of justice there are also economic arguments that are important to motivate qualified females and to lead them into management positions. The increase of women in leadership positions is not yet regulated by the German government. But there are other possible reasons for the low number of women in leadership positions which are described in this paper. In particular, values, and in this context the change in values, represents an important aspect of the cultural and social behaviours. This factor has in turn a strong impact on the role of women in the society.

In the end, political, organizational and cultural recommendations are given to minimize this gender gap in management. Norway is often seen to have a pioneering role in the solution of this problem (Statista, 2015; Reimann, 2012; Hofmeister and Hünefeld, 2010). From the example of Norway and other best practices, we can derive at practical recommendations to increase the number of women in management positions and act as a positive example in Europe and in the world.

\section{Leadership Positions in Germany}

In 2001, the German economy required managers to bring more women in leadership positions, but despite this great need, executive and supervisory boards especially in large companies continued to be in men's hands (Holst and Kirsch, 2015). The federal minister of Family, Senior Citizens, Women and Youth in Germany has emphasized that the German constitution guarantees in its third article, the equal participation of men and women, but it is still not common in most companies.

To implement and ensure equality in opportunities for women and men in German companies the government has recently decided to introduce a quota for women in management positions (Federal Ministry for Family Affairs, Senior Citizens, Women and Youth, 2014). On December 31st of 2014 the federal government cabinet has officially confirmed the draft for a law which will be implemented in 2016 and should guarantee equal participation of women and men in executive positions in private industry and public services (Federal Ministry of Justice and Consumer Protection, 2014).

The rate of women on the executive boards in Germany was 1.2 percent in 2006. This proportion increased slightly in the following years. Eight years later, the proportion of women which were part of the executive boards of the top 200 companies was only 5.4 percent at the end of 2014 (see figure 1). Overall, this was only about 1 percent more than in 2013 (Holst and Kirsch, 2015). 
Figure 1: Executive boards in the largest 200 German companies.

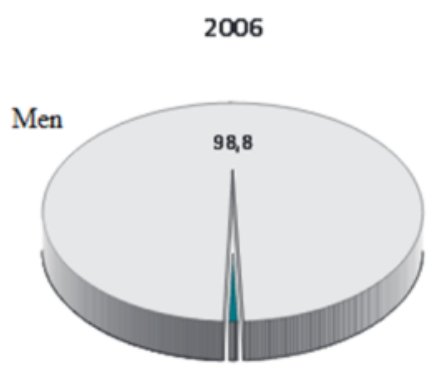

Women 1,2

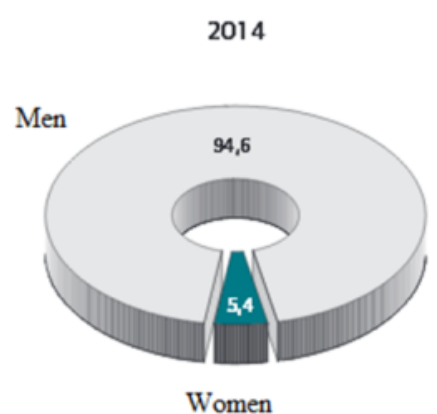

Women

Source: Holst and Kirsch, 2015.

According to a study on German firms, every fifth of the top 200 companies is employing women in the executive boards, which is 22 percent in total during 2014 (Holst and Kirsch, 2015). In absolute terms, there are 47 female directors on a total of 877 board seats. The situation of women on supervisory boards in the top 200 companies is a little bit better. Women were represented on 86 percent of supervisory boards.

The proportion of women has risen to about 18 percent in 2014 . These are three points higher than in 2013. Due to this positive development, women only filled 397 of 2156 supervisory board positions in German companies. In the DAX-30 we had a proportion of 25 percent in 2014, which can probably be accounted for by the public discussions about gender quotas.

If the figures for the top 100 companies only are taken into account, the share of women in top management boards has in fact fallen from nearly 5 percent to just a little more than 4 percent. In the top 200 listed company groups, the share of female chairs in 2014 in the executive boards ranged from 0 to over 2.2 percent and 0 to almost 7.4 percent in the DAX-30 (Hucht, 2015; Holst and Kirsch, 2015).

The representation of women on supervisory boards increased at the end of 2014, almost 18 percent of board members in the top 200 companies were female. The DAX-30 companies had above-average results for female board members with close to 25 percent. But on both executive and supervisory boards the female chairperson is still the exception. Compared to 4 female CEOs, 179 of these positions on executive boards in the top 200 companies were filled by men.

There was not even one female CEO in the 100 largest companies in Germany in 2014. With only 3 percent of all supervisory chairs, women's representation stayed very low, as shown in figure 2. Figure 3 shows the female CEO percentage in DAX-30 companies in comparison to those located in other countries largest publicly listed firms.

So, with fewer than 5 percent, women are significantly underrepresented in the world's largest companies and with 0 percent particularly in Germany during 2013. This fact demonstrates that the gender gap in management positions is not only strongly represented in Germany but this is also the case in many other countries throughout the world. 
Figure 2: Women on executive and supervisory boards in Germany's largest 200 firms

\begin{tabular}{|c|c|c|c|c|c|c|c|c|c|c|c|}
\hline & \multicolumn{9}{|c|}{ Top 200} & \multicolumn{2}{|c|}{ Top 100} \\
\hline & 2006 & 2007 & 2008 & 2009 & 2010 & 2011 & 2012 & 2013 & 2014 & 2013 & 2014 \\
\hline \multicolumn{12}{|l|}{ Executive bourds / management boards } \\
\hline Total number of companies & 200 & 200 & 200 & 200 & 200 & 200 & 200 & 200 & 200 & 100 & 100 \\
\hline With data on œmposition & 195 & 184 & 191 & 187 & 195 & 197 & 200 & 195 & 197 & 97 & 97 \\
\hline With women on exeative board & 9 & 15 & 17 & 16 & 22 & 22 & 33 & 35 & 43 & 19 & 17 \\
\hline Percentage & 4.6 & 8.2 & 8.9 & 8.6 & 11.3 & 11.2 & 16.5 & 17.9 & 21.8 & 19.6 & 17.5 \\
\hline Total number of members & 953 & 893 & 934 & 833 & 906 & 942 & 970 & 906 & 877 & 484 & 461 \\
\hline Men & 942 & 877 & 911 & 812 & 877 & 914 & 931 & 866 & 830 & 461 & 442 \\
\hline Women & 11 & 16 & 23 & 21 & 29 & 28 & 39 & 40 & 47 & 23 & 19 \\
\hline Percentage of women & 12 & 1.8 & 2.5 & 2.5 & 32 & 30 & 4.0 & 4.4 & $5 A$ & 4.8 & 4.1 \\
\hline Total number of chairpersons & 195 & 184 & 191 & 187 & 195 & 198 & 198 & 194 & 183 & 97 & 92 \\
\hline Men & 195 & 184 & 190 & 186 & 193 & 197 & 196 & 190 & 179 & 96 & 92 \\
\hline Women & 0 & 0 & 1 & 1 & 2 & 1 & 2 & 4 & 4 & 1 & 0 \\
\hline Perce ntage of women & 0.0 & 0.0 & 0.5 & 0.5 & 10 & 0.5 & 1.0 & 2.1 & 2.2 & 10 & 0.0 \\
\hline \multicolumn{12}{|l|}{$\begin{array}{l}\text { Supervisory boards / administrative } \\
\text { boards }\end{array}$} \\
\hline Total number of companies & 200 & 200 & 200 & 200 & 200 & 200 & 200 & 200 & 200 & 100 & 100 \\
\hline With data on composition & 170 & 145 & 168 & 153 & 166 & 103 & 170 & 157 & 155 & 86 & 85 \\
\hline With women on supervis ory board & 110 & 101 & 124 & 110 & 117 & 118 & 128 & 123 & 133 & 71 & 76 \\
\hline Percentage & 64.7 & 69.7 & 73.8 & 7.9 & 70.5 & $72 A$ & 75.3 & 78.3 & 85.8 & 82.6 & 89. \\
\hline Total number of members & 2500 & 2268 & 2466 & 2175 & 2293 & 2268 & 2369 & 2159 & 2156 & 1231 & 1232 \\
\hline Men & 2304 & 2074 & 2236 & 1961 & 2050 & 1999 & 2064 & 1834 & 1759 & 1044 & 1003 \\
\hline Women & 196 & 194 & 230 & 214 & 243 & 269 & 305 & 325 & 397 & 187 & 229 \\
\hline Perce ntage of women & 7.8 & 8.6 & 9.3 & 9.8 & 10.6 & 11.9 & 12.9 & 15.1 & 18.4 & 152 & 18.6 \\
\hline Total number of chairpers ons & 170 & 145 & 168 & 153 & 167 & 18 & 171 & 160 & 149 & 87 & 84 \\
\hline Men & 18 & 143 & 166 & 151 & 165 & 164 & 168 & 156 & 144 & 83 & 81 \\
\hline Women & 3 & 2 & 2 & 2 & 2 & 3 & 3 & 4 & 5 & 3 & 3 \\
\hline Percentage of women & 1.8 & 14 & 12 & 1.3 & 1.2 & 1.8 & 1.8 & 2.5 & 3.4 & $3 A$ & 3.6 \\
\hline $\begin{array}{l}\text { Companies with data on employee } \\
\text { representation }\end{array}$ & 123 & 108 & 129 & 103 & 110 & 105 & 118 & 83 & 118 & 46 & జ \\
\hline Total number of members & 2206 & 1773 & 1910 & 1732 & 1506 & 158 & 1638 & 1291 & 1869 & 748 & 1043 \\
\hline Men & 2023 & 1616 & 1742 & 1563 & 1360 & 1391 & 1438 & 1088 & 1521 & 640 & 845 \\
\hline Women & 183 & 157 & 168 & 169 & 146 & 176 & 200 & 203 & 348 & 108 & 198 \\
\hline Female employee representatives & 139 & 117 & 125 & 121 & 105 & 119 & 117 & 110 & 200 & 61 & 113 \\
\hline As a percentage of women members & 76.0 & 74.5 & $74 A$ & 71.6 & 7.9 & 67.6 & 58.5 & 542 & 57.5 & 56.5 & 57.1 \\
\hline
\end{tabular}

Source: Holst and Kirsch, 2015.

Figure 3: Women CEOs of public listed companies.

\begin{tabular}{|c|c|c|c|}
\hline Stock exchanges & Percentage & Stock exchanges & Percentage \\
\hline OECDי & $<5.0$ & European Union² & 2.8 \\
\hline Latin $500^{3}$ & 1.8 & FTSE 100, UK ${ }^{4}$ & 4.0 \\
\hline US Fortune $500^{5}$ & 4.8 & ASX 200 Australia $^{6}$ & 3.0 \\
\hline JSE South Africa? & 3.6 & BSE 100 India $^{B}$ & 4.0 \\
\hline Mexico Expansion $100^{9}$ & 3.0 & 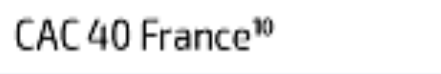 & 0.0 \\
\hline SGX Singapore" & 4.6 & DAX 30 Germany ${ }^{12}$ & 0.0 \\
\hline China ${ }^{13}$ & 5.6 & NZSX 100 New Zealand ${ }^{14}$ & 5.0 \\
\hline
\end{tabular}

Source: Bureau for Employers' Activities (ACT/EMP), 2015. 
A closer inspection of companies, in Germany in 2012, shows that the representation of woman in general and management positions is decreasing according to the size of the company. Figure 4 shows this problem clearly and illustrates at the same time that in the lower management positions women have better representation. The second management level is achieved by females about 1.5 times more in comparison to the first level. Nevertheless the fact that approximately half of the employees are women demonstrates that there is a problem of gender gap in the highest management positions, it also shows that there is an underrepresentation of females in these modern companies (Kohaut and Müller, 2015; Pfahl, Hobler and Oerder, 2014).

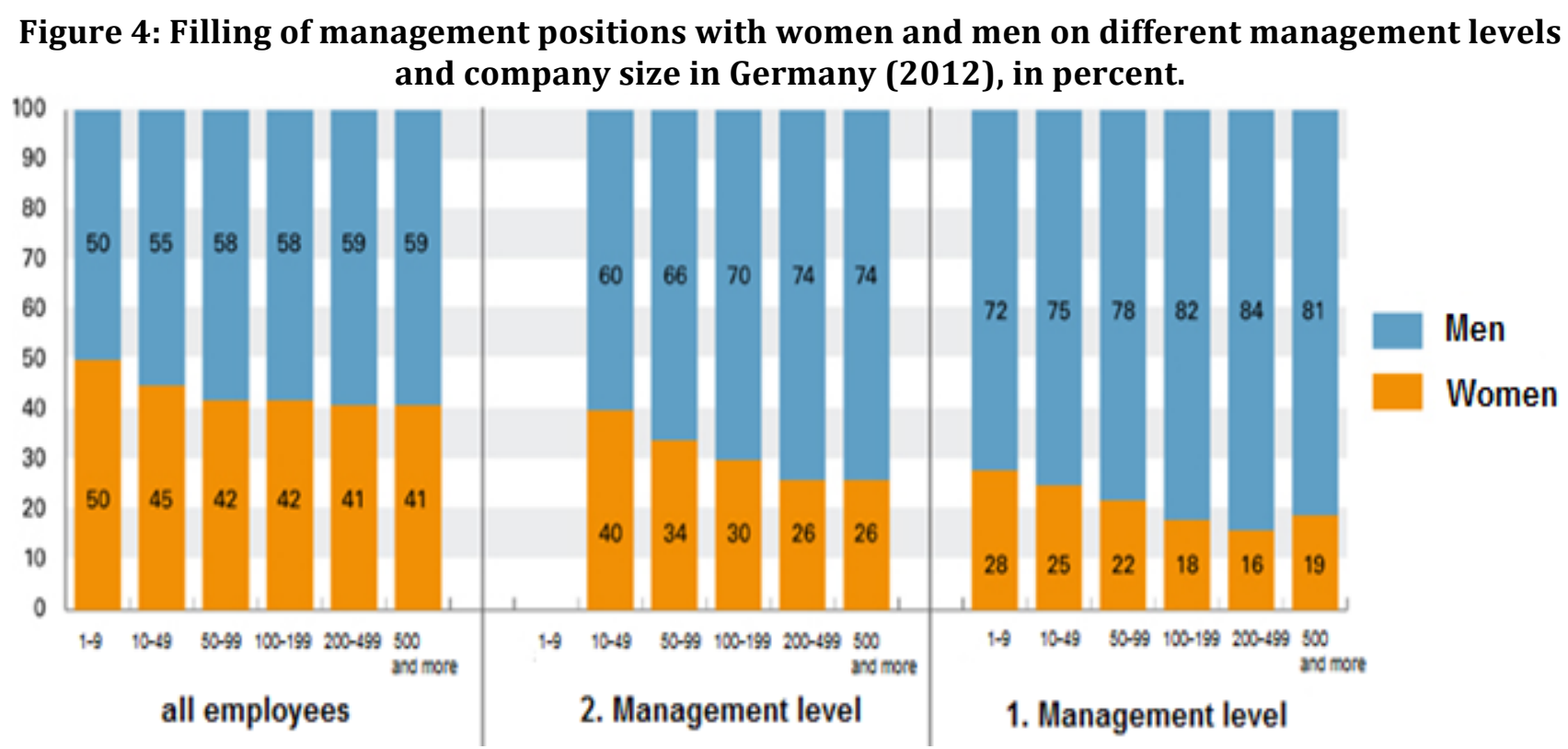

Source: Pfahl, Hobler and Oerder, 2014.

To underline the topic above a survey found that the number of women reaching higher management levels was increasing in 2013. After all they remain mainly in managerial functions such as human resources, public relations, communications, finance, and administration. Only a few international companies that were involved in the survey employed women in managerial functions like research, product development, sales, operation, and general managers.

This illustrates the fact that most of the women do not have such extensive experience in management or rather in the divisions which are necessary for a promotion to the executive squad (Bureau for Employers' Activities (ACT/EMP), 2015; Hofmeister and Hünefeld, 2010). However, not only in an enterprise but also in different private industry sectors there is a tendency to cluster females in particular branches in Germany. With 46 percent in 2012, most of the women are represented at the first management level in service sectors like health and education.

A high proportion of women in total and in leading positions are in the retail, hospitality, economic, scientific and freelance service sectors. Nevertheless the number of women in the first management level is much lower than those of men. Branches like financial and insurance services stick out by the fact that the level of female employees, which is around 55 percent, is higher as in other branches. Only 11 percent are represented in the first management level. Other industrial fields such as the information and communication sector, wholesale and 
automotive retail and repair or manufacturing industry are held almost exclusively by men which also indicate that the executives are majority men (Kohaut and Müller, 2013).

The situation in Germany illustrates that voluntary commitment by the companies to implement more women in the high management positions did not obtain the desired success (Deutscher Bundestag, 2015). It is very clear that much has to be done to combat the disparity between women and men in the working environment. But before that can happen, let us discuss some of the reasons for the gender gap disparity in management.

\section{Reasons for the Gender Gap in Leading Positions}

The main question is concerned with the reasons for the gender gap in the leading positions in Germany. Why are women in leading positions underrepresented?

The statistical portal Statista brought a statistical study from over 18,000 sources in Germany in 2015 for this question. Figure 5 shows the result of a survey of executives on the reasons for the low proportion of women in leadership positions. The two main reasons for the difference are lack of reconciliation of work and family with 73 percent, and lack of flexibility of the companies with 54 percent. Around 32 percent regard the fault of women's motivation as the decisive point. Furthermore, for 25 percent the missing role model is the reason for their behaviour of not going into management. Another 25 percent is blatant discrimination toward women, and 17 percent are other reasons (Statista, 2015).

\section{Figure 5: Why are women underrepresented in management positions in Germany?}

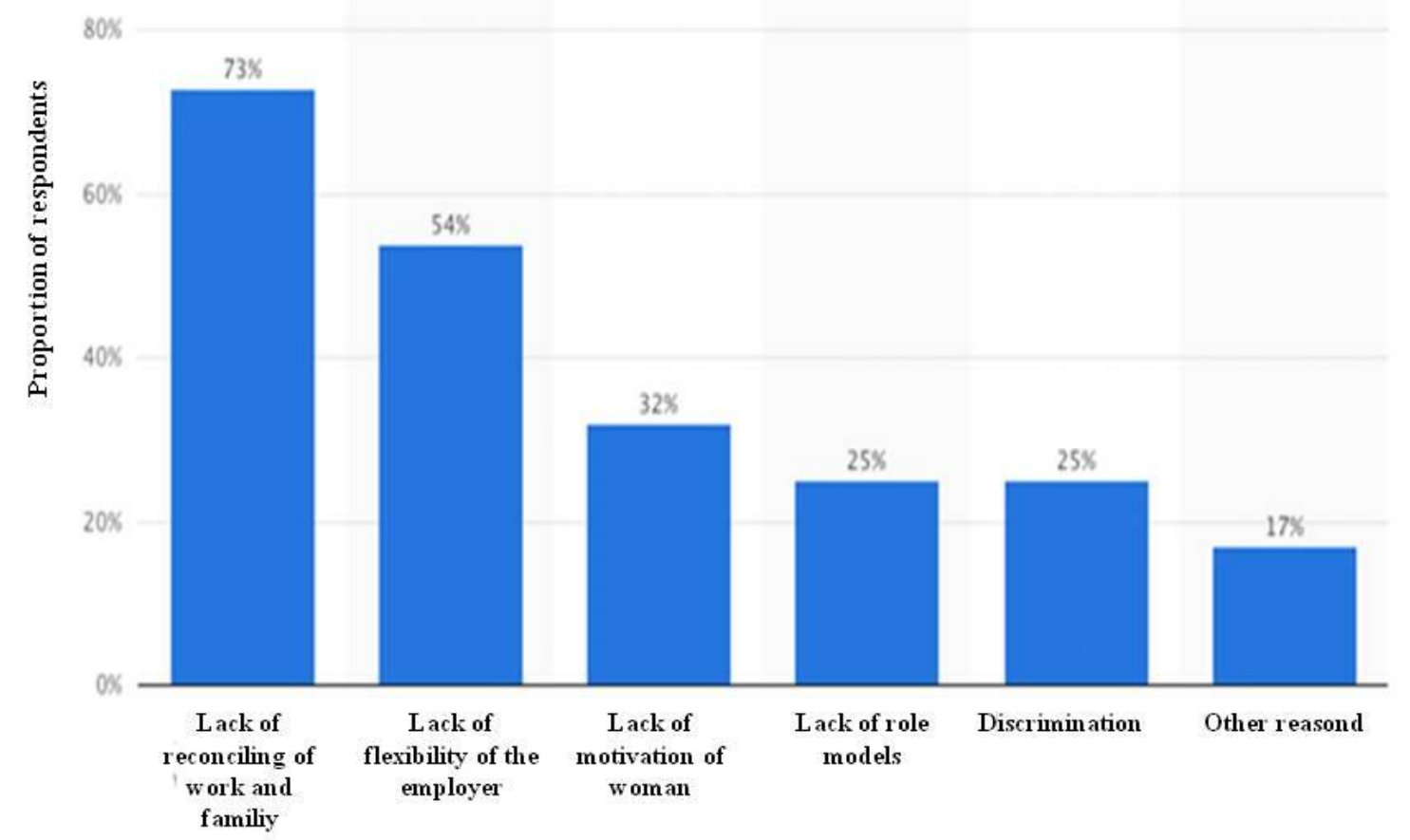

Source: Figure data based on Statista, 2015 a.

The reconciliation of family and working life represents one important reason for the underrepresentation of women in management positions. For women it is a challenge to combine these two areas of life because of the fact that tasks between a man and woman in the family and housework are not distributed evenly. This is supported by the fact that society still expects women to be mothers and to relieve men from such responsibilities and tasks. 
Additionally, most single-parents are women, so even the single-parenthood is seen as a woman's task. The work-life-balance is a challenge especially for single-mothers because they have the responsibility for the economic situation, childcare, and recreational activities. So women in employment and especially in management positions have to handle the double pressure and are, at times, classified as uncaring mothers.

The compatibility of children and career for females are more difficult because of the missing of suitable work-life models and lack of sufficient facilities for childcare. As a result women have more interruptions in their career development, and their promotional prospects are getting worse. Also, part-time job is often a necessity for women's employment and family, and this supports the problem of gender gap in leadership positions because the decision for this kind of work is not always voluntarily chosen (Hofmeister and Hünefeld, 2010; Federal Statistical Office, 2014; European Commission, 2014). Better conditions for the reconciliation of family and working life inside and outside of the company would help to increase the number of women in management positions. This means that all actors in the society such as government, economy and families have to contribute to ensure that employment and family responsibilities are adopted more equally between men and women (Confederation of German Employers' Associations (BDA), 2014; Kleinert, 2006).

Another reason for the underrepresentation of women in management position is the lack of flexibility of the employers. In order to survive in international competition, companies have to integrate diversified management teams with men and women being equally represented in all leadership positions. Actually, large enterprises are highly hierarchically-orientated and tend to have male dominated structures. Only in some departments such as human resources or public relations, there is often a higher representation of women in management positions. But to achieve a higher management position, some business areas are seen as "dead-ends" as they do not lead to senior positions.

Some companies in general see women as risky employees because of their ability to give birth and go on maternity leave, or they may even quit the job when they become housewives or mothers. Furthermore, larger companies use highly formalized recruitment procedures, which are disadvantageous for women, because they are based on male-orientated full-time working models and assess job interruptions as a loss of qualification.

In addition to this, companies have implemented rigid attitudes based on stereotyped role models of women which represent the view that women and leadership are not compatible (Hofmeister and Hünefeld, 2010; Bavarian State Ministry of Employment and Social Order, the Family and Integration, n.d.; Wippermann, 2014).

The inflexibility of employers demonstrates that companies should implement more flexible working conditions with regard to consideration of time and space. This means that companies have to invest in intervention measures which support and encourage women in the execution of their management tasks.

Therefore they should create and implement flexible corporate cultures which should not only ensure family friendliness, the arrangement of flexible working hours and location, but also guarantee equal opportunity in the achievement of management positions in all corporate areas (Hofmeister and Hünefeld, 2010; Bavarian State Ministry of Employment and Social Order, the Family, n.d.; International Labour Organization, 2015). 
The Lack of motivation is the result of many factors. The missing female role models or role models in top management can cause the problem of identification. Women hardly recognize their gender in executive boards and management positions. In addition, many women miss the appreciation of their immediate supervisor. Some women are frustrated by the lack of recognition and encouragement from their bosses and colleagues. Many women also have the experience that although they invest much time in the career development, but still get passed over for promotions that become available.

They work hard, but at a certain point they are not going any further up the hierarchy, facing the "glass ceiling" which is also known as the "concrete ceiling" which cannot be shattered as easily as the glass ceiling. Additionally family-friendly work structures and measures to facilitate reconciliation of family and career for improving living and working conditions for both gender are missing. Gender-sensitive and equal opportunities to working conditions are a decisive factor for long-term retention of qualified employees to the company. The gender pay gap also causes a lack of motivation; thereby leading to women missing the incentive to ascent in management positions (Austrian Industry Association, 2012).

Another important reason is the deficit of successful female role models in the economic environment, especially in management positions. The reason for this is that women are generally underrepresented in leadership positions. Therefore women in leading positions are necessary, because they motivate other talented females to follow their example. Role models can act like a "magnet" for women in general and especially young professionals. Some studies show that a high number of women in leading positions would have a positive influence on thinking patterns in a company and could introduce changes at the structural level. One particularly interesting aspect is that women in management positions who are also full-time working mothers achieve a higher salary level more frequently than those who are not mothers. Mothers of high-income women are characterized by the fact that they represent the lowest proportion of unemployed females. Consequently mothers in leadership positions act as role models and influence the financial success of their daughters. Females, whose mothers carry out the double burden of family and work, are not usually scared of managing and having children, rather they learn that the multitasking occupation of a woman is natural.

An underrepresentation of women in companies and in management positions may create the impression that women are undesirable for leadership positions. This fact can easily demotivate potential future qualified female managers and women who are already in management positions. Therefore the question needs to be asked: What kind of potential has a company when more than half of competent talents are excluded for a leadership position? (Peuß and Welpe, 2011; Holst and Wiemer, 2010; Wippermann, 2014; Bavarian State Ministry of Employment and Social Order, the Family and Integration, n.d.; Bavarian State Ministry of Employment and Social Order, the Family and Women, 2010).

The gender pay gap is one sign that we have not overcome discrimination and inequality in the labour market. In discrimination, the problem is that the way women's competencies are valued compared to men's. Women with similar qualifications, skills and experiences are often poorly paid and undervalued than men. In addition to the evaluation of performance, women's pay level and career development are also biased in favour of men. Germany is one of the countries within Europe, where the gender pay gap between men and women is the greatest for equal education and work experience. The European average is $17.6 \%$ where women get paid less than men. Germany with a $23 \%$ gap belongs to the top of the countries in which women are discriminated by a lower salary. This problem is very complex and has various 
causes. So politics and certain practices belonging to the causes end up in an unequal treatment of men and women. Also the work industries and jobs in which the work can be better reconciled with family is a cause for this problem. As a result of this women are working in part-time or low-paid occupations and management positions are neglected. Moreover, women are also associated with feminine qualities and not always regarded as having the required skills and competencies, so their abilities are often undervalued. This can lead to a gender bias effect in salary setting and the evaluation of women's performance. But some employers mention specific stereotypical reasons for the preferential treatment of men and the discrimination of women that females have a lower productivity, higher failure times because of care for children and relatives, and they have lower assertiveness (European Commission, 2014).

Stereotypes and traditions are certainly responsible for segregation of men and women in the professional world and may influence the choice of educational paths and professional careers. Consequently, fewer women are working in technical jobs and because of the tradition in which society expected women to reduce their working hours or even quit their jobs to take care of children (Hofmeister and Hünefeld, 2010). The more important fact is that some stereotypes are deeply-held in the mind of managers because of the outdated image and perceived role of women in society, but these biases still have a big importance in the workplace as the influence behaviour (Bavarian State Ministry of Employment and Social Order, the Family and Women, 2010).

The obsolete idea is that a successful career can only be achieved by a man who has the most working experience without any family interruptions. The result is that male managers are perceived as authoritarian, status-oriented, confident, assertive, and ambitious. Female managers are often classified as emotional, sensitive, communicative, diplomatic, and disciplined (Rettig, Engeser and Schmidt, 2013). The German Federal Ministry of Family, Seniors, and Youth has conducted a survey on the attitude of managers towards women in management positions and shows how stereotypes and role models influence one's attitude and behaviour. The result of this survey is existing barriers of men-mind-set in management positions. On the one hand, men expressed great appreciation for competent and ambitious women and showed consent to an increase of women in leadership positions. That means that an important milestone of the acceptance of women is achieved.

On the other hand, there is no increase in the chances of female candidates filling leadership positions. This fact can be explained by the reservations about women in executive positions which are firmly anchored in men's mind. So men act as "guardian of the glass ceiling" (Wippermann, 2014). This "glass ceiling" expression is a metaphor and includes all invisible processes and factors that prevent women from access to leadership positions. These processes include the male culture in companies, whereby mentality patterns have been formed, the lack of role models, and management cultures with their own rituals, language games and habits that favour men.

Consequently men are encouraged by their male superiors, while opportunities for women are denied and this fact causes the manifestation of the current situation and gender gaps in management levels. This means that from the perspective of men, women are not capable for top management positions because of the traditional gender roles, and there is a basic negative attitude towards women in leadership ranks (Hofmeister and Hünefeld, 2010). Some competent women shy away from leadership positions because they are concerned that they 
need to do more as a woman or because of the higher pressure of expectations than men in the same position (Wippermann, 2014).

Why there are so many stereotypes and clichés about men and woman? Which factors are responsible for the attitude, judgment, decision-making and motivation? According to some social-psychological theorists, culture and the prevalent value system are responsible for much of the stereotypes. According to Milton Rokeach, a value is an enduring belief that a specific mode of conduct is personally or socially preferable to an opposite conduct or end-state of existence (Rokeach, 1973). Accordingly, values are enduring personal and social beliefs that determine, whether a lifestyle or a target state is desirable or not. These beliefs represent knowledge and experience that a person has accumulated in its development history.

According to the attitude theory by Kahle (1983), values are similar to attitudes and needs, because these are abstractions arising from adaptation, organization and interpretation of environmental information. All values are organized in a value system, a skilled organization of rules and principles that are structured in a hierarchy and are responsible for directing reactions of stimuli. People, to a certain extent, have similar values, regardless of culture and society. Although people have many of the same values, these are situated hierarchically differently. The number of these values or rank is limited in each individual and differing only in the expression intensity.

Values also exhibit a certain degree of stability, thereby indicating human orientation through an extended period. But values are also modified, at times, so they can cause social change. Values affect consciously and unconsciously human behavior and have multiple functions. The meaning of values results from the fact that they act as standards of judgment and thus influence behavior. Summarized values have an orientation and motivation function and contribute to conflict resolution, decision making and for the alternative choice (Kahle, 1983). Out of values emerge attitudes and beliefs, which in turn control and influence perceptions, emotions, behavior and lifestyles and are an expression of human needs. Thus, the pursuit of different goals accordingly has different psychological, practical and social consequences (Schwartz, 1992). They are the result of socialization through important reference groups.

Values are therefore important because through them people are able to define themselves and can express these differences to others. Finally they are cognitive representations of goals that demonstrate the interest of social groups, coordination of behavior, communication and interface between the collective and individual behaviors. Values are cross-culturally universal, but the importance of each value system between cultures and individuals is different (Schwartz, 1994). Therefore, the cultural aspect has a major importance.

Hofstede said that "Culture is the collective programming of the mind which distinguishes the members of one human group from another.... Culture, in this sense includes systems of values, and values are among the building blocks of culture" (Hofstede, 1984, p. 21). This implies that a culture is particular to one human group, is learned and not inherent, and passed down from one generation to the next. Culture is an abstract construct that results from many factors and not only affects the behaviour, it also shapes personal characteristics, gender stereotypes, age, genetic profile and social constraints, imposed by family and social class (Mead and Andrews, 2009). The iceberg model shown in figure 6 represents that culture exists of tangible (visible) and intangible (invisible) elements relating to each other. Intangible elements such as values and attitudes influence the tangible elements of behaviour. So the intangible elements are forming the basis for all visible effects. 
Figure 6: Iceberg model applied to culture.

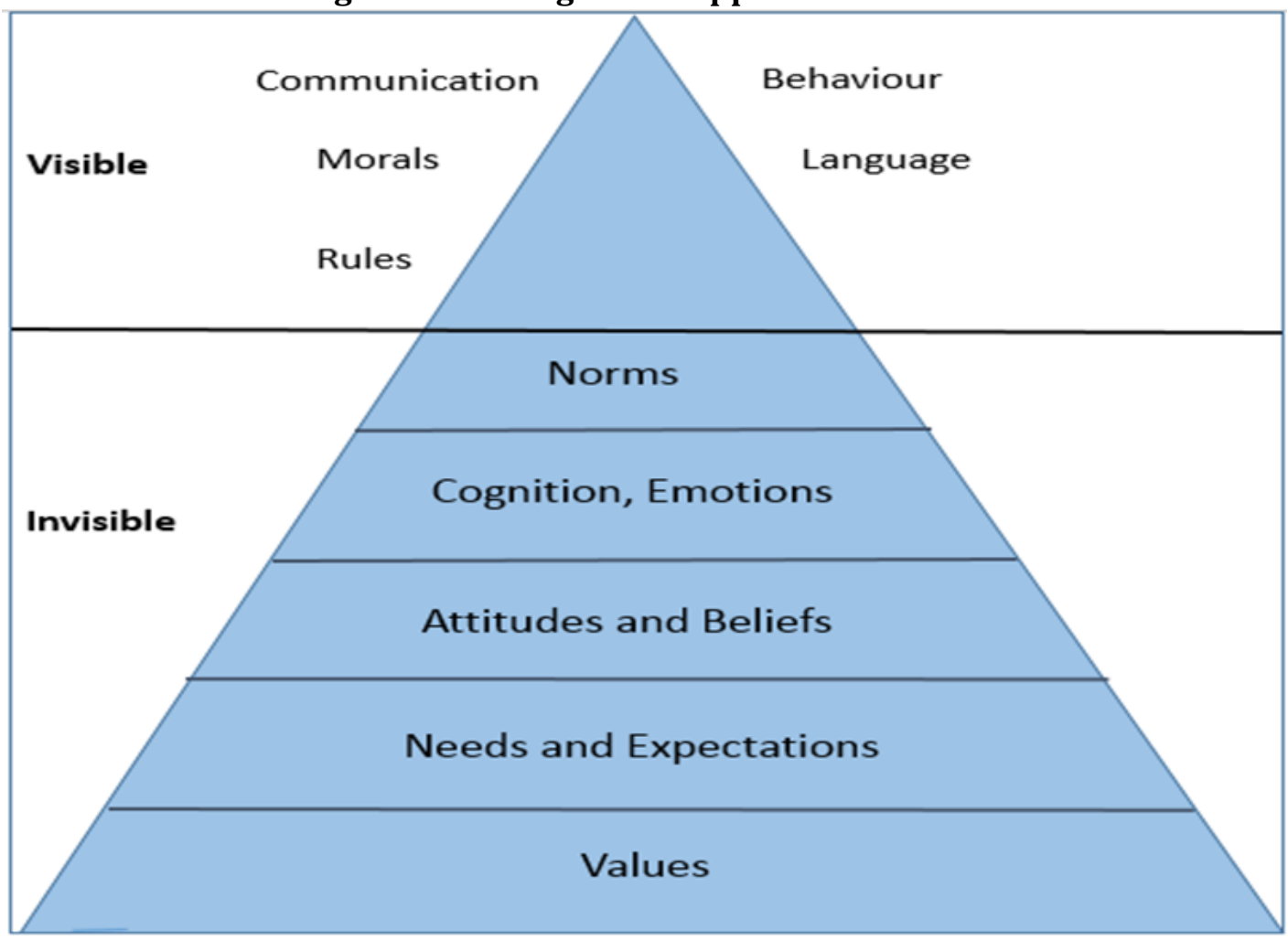

Because of the important function of values it is necessary to analyze the values of the German population to explore its possible links to the prevailing gender gap in leadership positions. The Opinion Research Institute Emnid commissioned a two part representative survey of 1002 respondents at the beginning age of 14 years. For 74 percent of respondents the value of "honesty" was very important. "Family" reached with 68 percent in the second place. The third most important value is "equity" with 64 percent (Kochanek, 2007). The Western Value Index of 2014 demonstrates that the current and important social values of the German population changed which are health, freedom and success.

Especially the value of success makes a big leap forward. In particular, this value plays an important role in business and working environment and consequently for the main question of this paper. The material wealth is no longer at the center point, but the realization of personal goals and aspirations seem to fill this void (Trendbüro and TNS Infratest, 2013; Ehrenstein, 2013). In recent years a "values-change" has taken place in the population with a tendency that the value of success is becoming more and more important, but was not considered in the company-culture.

Finally, the above-mentioned reasons have underlying causes that lie in the culture and its values. The culture includes values and incurring roles and traditions that contain mechanisms of their own reproduction and the exclusion of others. Therefore, it is necessary to take suitable measures, which not only should be political, legal and operational but also cultural.

Stereotypes and traditions are also responsible for segregation of men and women in the professional world and may influence the choice of educational paths and careers along with their thinking about role allocation. Consequently fewer women are working in technical jobs because of the traditions the society expect women to reduce their working hours or even quit their job to take care of children (Hofmeister and Hünefeld, 2010). The more important fact is 
that stereotypes occupy the mind because of the outdated perception and role image, and they have a big influence in the workplace in negatively impacting women (Bavarian State Ministry of Employment and Social Order, the Family and Women, 2010). The obsolete idea is that a successful career can only be achieved by men who have the most work experience (Rettig, Engeser and Schmidt, 2013).

\section{SWOT Analysis of Women in Management Positions}

This section is divided into two successive stages. The first one involves the SWOT analysis. The SWOT analysis is a structured documentation and classification tool, which can be used to understand the problem of women in management positions by looking at the existing strengths, weaknesses, opportunities, and threats (SWAT) to this gender-gap dilemma. The second part comprised the result of the SWOT analysis as a basis for recommendations to improve the integration of more women in management positions.

In academic and business elaborations, SWOT-analysis is one of the popular used tools to analyze a situation and to create strategies for recommendation to management and its eventual implementation.

For obtaining a structured and comprehensive overview of the strengths, weaknesses, opportunities, and threats of the actual situation, the concept of SWOT analysis is used to better understand the dilemma and its solutions. It is applied to show the dilemma in management positions of women in the corporate arena. The analysis is performed in the following three steps, whereby the third step is modified to our case of gender gap in management positions:

1. Analysis of internal strengths and weaknesses of women in management positions.

2. Analysis of external opportunities and threats to women in management position.

3. Compare and aggregate the two steps to offer recommendations (Runia, et al., 2007).

In this case the SWOT-Analysis concentrates on main points for an overall view to show the gap problem of women in management positions.

Table 1: Internal strengths and weaknesses.

\begin{tabular}{|c|c|}
\hline Strength & Weakness \\
\hline $\begin{array}{l}\text { - } \begin{array}{l}\text { Effect to lower management positions in the } \\
\text { adapting company } \\
\text { - }\end{array} \text { Stimulation for other women to work on this } \\
\text { kind of level and to apply } \\
\text { - } \quad \text { A decision between work or family is not } \\
\text { necessary } \\
\text { - } \quad \text { Increase of work-life-balance quality for } \\
\text { both gender causes a positive effect on work } \\
\text { - } \quad \text { Increases the reputation of the company for } \\
\text { employees } \\
\text { - Variability in management positions brings } \\
\text { more compensation in minds } \\
\text { - Increase of profitability through positive } \\
\text { spillover effect }\end{array}$ & 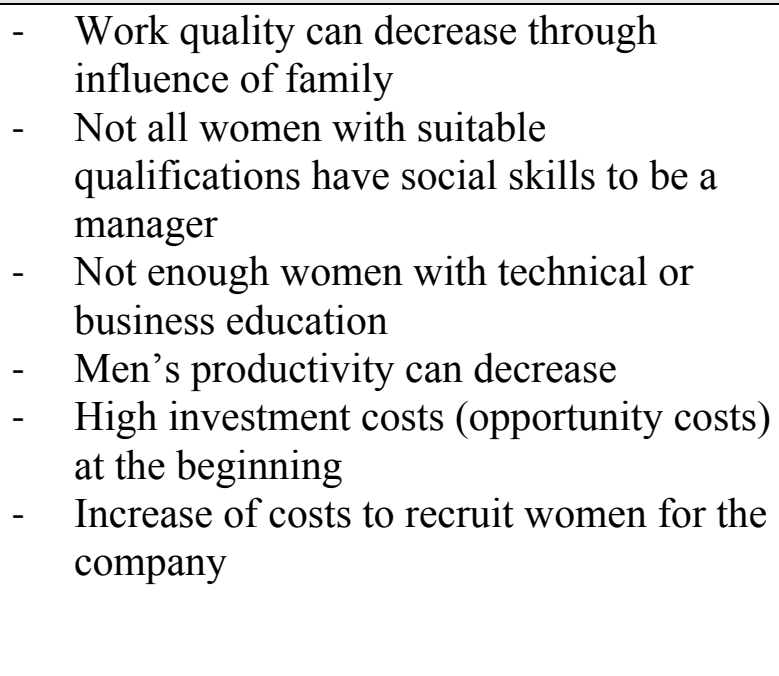 \\
\hline
\end{tabular}


Table 2: External opportunities and risks.

\begin{tabular}{|c|c|}
\hline Opportunity & Threat \\
\hline $\begin{array}{l}\text { A general effect to lower management } \\
\text { positions in companies } \\
\text { Stimulation in society for other women to } \\
\text { work on this kind of level in working } \\
\text { environment } \\
\text { Higher attractiveness for women to apply } \\
\text { for management positions } \\
\text { A decision is not necessary between work or } \\
\text { family } \\
\text { Increase of work-life-balance quality for } \\
\text { both gender causes a positive effect on } \\
\text { social life } \\
\text { Increase of profitability through positive } \\
\text { spillover effect } \\
\text { Increase of reputation of the company in the } \\
\text { environment } \\
\text { Increases the emancipation of women in } \\
\text { society } \\
\text { Compatibility between female quote and } \\
\text { demographic change }\end{array}$ & $\begin{array}{l}\text { - Family may have a negative influence on } \\
\text { work quality } \\
\text { - } \quad \text { Discrimination of men in companies and } \\
\text { society } \\
\text { - Compatibility between female quote and } \\
\text { demographic change }\end{array}$ \\
\hline
\end{tabular}

The SWOT analysis of women in management positions is providing many facts regarding the strengths and weaknesses in combination of opportunities and threats.

It can be seen that it is an advantage for women to work at a company, especially in management positions. Besides better teamwork and increased revenues, the acceptance of women on management or executive positions in companies and society has a positive effect on both sides. On the one hand, the company gets a better reputation in national and international boundaries. On the other hand, there are influences on lower management levels. Accordingly women in management positions represent role models for other females who might become more self-confident and more willing to apply for leadership positions. Nevertheless, women with technical or business education are not highly represented in the labor market. For example, Germany is focused on industry, especially in production.

The automobile industry is one key industry where most Germans are working and technical expertise is needed in management positions. Indeed an increasing number of women are studying business and leadership related subjects and going in this direction, but there are still not enough high level candidates for the industry. If professional females have suitable technical qualifications, they also need industry level social skills as well to be a successful manager in a male-dominated workplace.

This fact applies for women and men alike. However, if a woman has these skills then it is not necessary for her to decide between work and family. Otherwise there is the danger that through the influence of family their work suffers. Children and family are always the first priority and work comes second. Therefore work-life-balance is very important and, as the result, women should not have additional pressure to decide between career and family. They 
are able to make a career and also be good mothers for their children. Furthermore, the acceptance of emancipation of females in the society increases through this measurement.

The gender gap in management positions is a sensitive topic for men. The preferences for the occupation of women in leadership positions can decrease the productivity of men, because they can feel unaccepted, unqualified or misunderstood at the company or in the society. For this reason the work-life-balance is also bringing many advantages to men. They have the option to spend more time with their family, which can strengthen the family relationship and cause more vitality. Also the greater acceptance of women into management positions can create a spillover effect for the whole company and lead to more effectiveness and profitability at work.

Keeping the balance between increasing the number of female managers and the negative effects of the demographic change is a really difficult and also extremely important point. On the one hand, there is the risk of a negative development of the demographical change through the acceptance of women in management positions in companies and in society. But on the other hand, there is the possibility of equality in companies and in the society of the gender problem. This also causes more harmony in families.

If these ideas of equality between men and women are established in the society, it will be easier to plan the family and to raise children. The conditions for this become more practical and advantageous than before. The acceptance of women in management positions is not just a step for the equality of women's personality; acceptance of women in leadership hierarchy is also the right way to solve the problem of demographic change. All in all, the occupation of women in management positions brings many benefits for companies and the society.

\section{RECOMMENDATIONS}

The share of companies with a relatively balanced ratio of women to men on their executive and supervisory board is extremely small in Germany. Top management still remains predominantly male-dominated. Nevertheless every woman, who would like to work in leadership positions, should get the opportunity to do so. In order to increase these opportunities for female professionals and to solve the problem of underrepresentation of women in management positions, political, legal, operational, and communication measures should be adopted and pushed through. The following are several examples for recommendations:

1. Creation of transparency is an important measure, especially in recruitment and promotion to management positions. Also a high transparency concerning salaries and bonus payments would be a step in the right direction.

2. Measure and document women in management. The company management should identify the increase in the share of women in management positions as a corporate goal, to show that they are willing to change the existing gap in inequality. Also, it is important to create a more functional, economical and healthy working atmosphere.

3. The industry and society should support women to become active in areas such as mathematics, computer sciences and technology as well as in the natural sciences and engineering.

4. Corporate culture should be more open to women in management positions, and gender stereotypes should be dismantled. New role models in management positions could serve as helpful examples. Successful women could be highlighted to set a focus on them. 
5. Companies should respond to the acceptance of the new values. Management should use the new values with colleagues to make a more gender-neutral working atmosphere.

6. The introduction of flexible career models for women and men, the need to reconcile family and working life-balance should all gain more importance for both genders; for example, offer flexible childcare options. Also many working activities can be done at home through the new electronic infrastructure.

7. Introduce women's quota, with binding targets and a realistic timeframes for achievement. Moreover, management should realize a sustainable increase in the number of future female executives. In addition, incentives and sanctions for implementation should be agreed (Holst and Kirch, 2015; Mujtaba, 2014; Hofmeister and Hünefeld, 2010).

\section{OUTLOOK}

The dilemma of underrepresentation of women in management positions is present in many countries and they should solve it quickly. This paper showed how deep the problem of this dilemma is in Germany and other Western countries. Figure 7 shows that the Scandinavian country of Norway has the highest number of women in management positions with 39.5 percent. In contrast, Germany has a very low percentage of females in leadership positions with 11.2 percent. Compared to Norway, Germany only has about one quarter of the proportion of women in management positions (Statista, 2015).

The Norwegian model is a positive example for implementing women in management positions. The Norwegian government determined that the proportion of women on the boards of incorporated companies should be 40 percent in 2003 (Statista, 2015; Hofmeister and Hünefeld, 2010). The government was very strict in implementing the law. Companies had five years to comply with the quote. If a company does not make it within that period, they had to reckon with sanctions. In extreme cases, threatened as other serious violations of the incorporated company law, even the forced dissolution of the company. Through their pressure on the industry, they are the best example for usage of the female quote to represent woman in management positions. 
Figure 7: Proportion of women in management positions in selected countries worldwide.

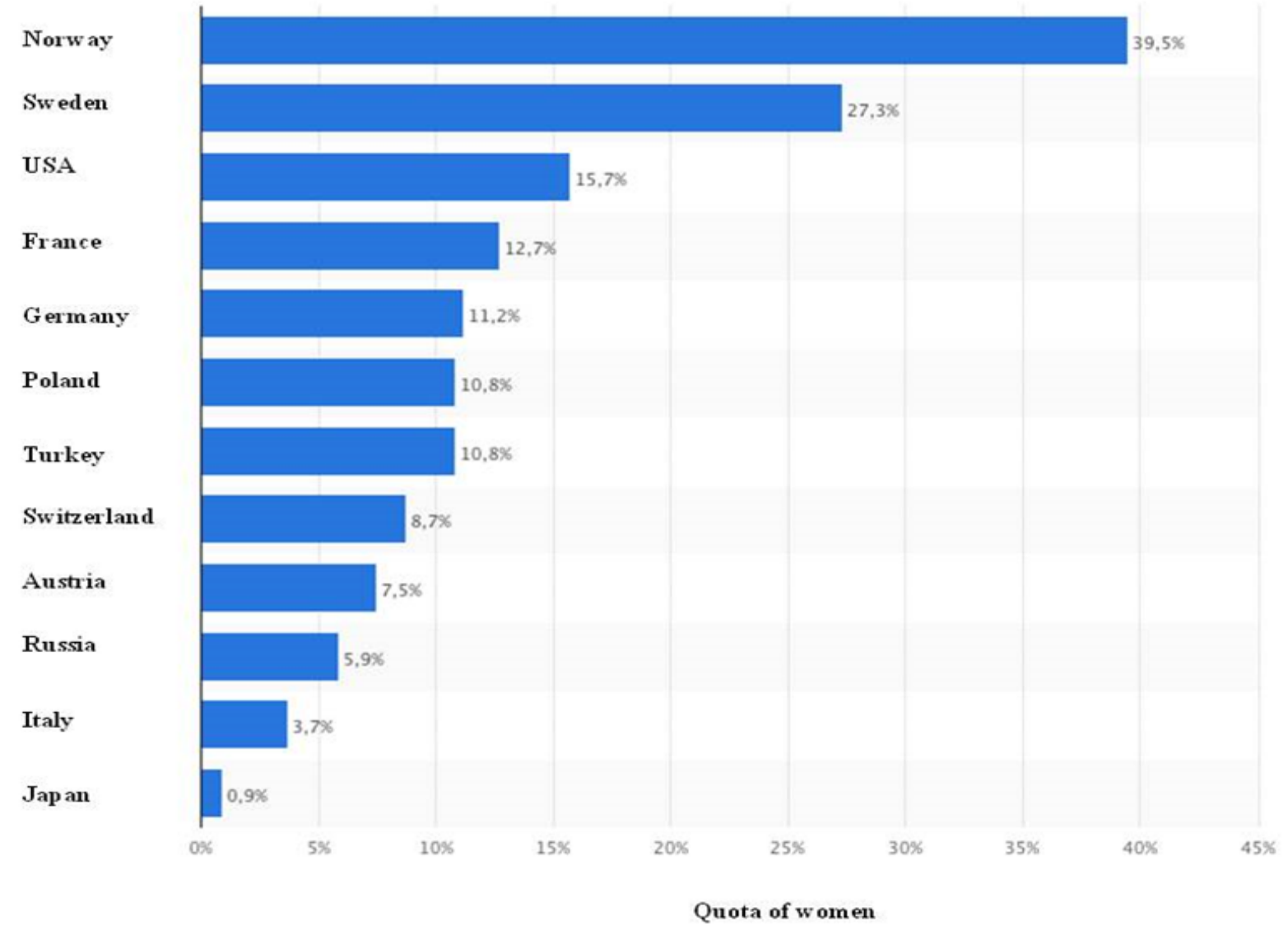

Source: Statista, 2015 b.

Norway is a role model for other European countries in terms of the female quote. The experience of this step shows that the legal compulsion brought success to Norwegian companies. Enough women with suitable qualifications were found for the boards of companies. The 40 percent quota is now exceeded in many firms. Twelve years ago, before the introduction of this law, women were represented on the boards with an average of seven percent. Now an expansion for most companies is in discussion. Furthermore, it seems like the proportion of women on the boards of incorporated companies also took a positive effect on the lower management positions (Reimann, 2012; Hofmeister and Hünefeld, 2010).

Germany has to change something to fight the disparity of gender inequality. Women are unfairly discriminated against in the occupation of boards in Germany and they should solve this dilemma as soon as possible. The German industry can be a role model in the world and they have the responsibility to manage this dilemma. Norway can be applied as a positive and successful example in the implementation of the female quota in management ranks. Their model of the statutory female quota is the right way to manage the problem.

Germany has recognized the problem and they are on the way to implement the female quota system at the beginning of 2016. It is expected that through this method the number of women in management positions in Germany will increase. In addition Germany should not neglect other measures, which are based on the above recommendations and which include values and cultures of the German population to improve the situation of women in management positions. Moreover, the improvement of female leadership positions should be considered as a 
worldwide ambitious goal to increase the equality of men and women in management ranks of modern and globally dynamic workplaces.

\section{SUMMARY}

In the last few years the proportion of women on executive and supervisory boards in Germany has slightly increased. The proportion of women which were part of the executive boards of the top 200 companies was only 5.4 percent at the end of 2014 . With the female CEO percentage in DAX-30 companies at 0 percent, women were significantly underrepresented in Germany during 2013.

This phenomenon of few females being in management positions can be explained by reasons like the lack of reconciliation of work and family, deficit of successful female role models, and gender discrimination. Women with similar qualifications, skills and experience are poorly paid and undervalued than men. In addition evaluation of performance, hence pay level and career development, also biased in favor of men.

Germany is one of the countries within Europe, where the gender pay gap between men and women is the greatest for equal education and work experience. The European average is 17.6 percent where women get paid less than men. Germany has a 23 percent gap and belongs in the top of the countries in which women are discriminated by a lower salary. These reasons are a result of attitudes and behavior derived from the Western values and especially the German culture.

Values have an orientation and motivation function, they act as standards of judgment, and that is why values serve as a foundation for human behavior and determine the role of women in society and consequently in leadership positions.

The SWOT analysis was used to further explore the problem of women in management positions. All previously necessary listed information's are collected and examined for goaloriented recommendations to change the dilemma of underrepresentation of women on executive and supervisory boards.

The usage of the female quotas, which is currently being introduced in Germany, represents an important measure for future improvements of equality in promotion between males and females aiming for management positions.

In the past, companies could solve this problem on their own; now it is the responsibility of government regulators and policy makers to achieve the social mission of gender equality in the workplace. In addition, improvements in areas such as work-life balance and the elimination of traditional gender stereotypes should not be neglected. When men and women work side-by-side creatively, there is no end to their synergy and success in better serving society. 


\section{References}

Austrian Industry Association (2012). Frauen in Führungspositionen: Ein Leitfaden für Unternehmen. Retrieved February 14, 2015, from

http://www.bmwfw.gv.at/Ministerium/Arbeitsgruppe\%20f\%C3\%BCr\%20Gleichbehandlungsfragen $\% 20 \mathrm{im} \% 20$ BMWFW/Documents/Frauen_F\%C3\%BChren_2012.ENDVERSION.pdf.

Bavarian State Ministry of Employment and Social Order, the Family and Integration (n.d.). Frauen in Führungspositionen: Frauen sind in Führungspositionen unterrepräsentiert. Retrieved February 14, 2015, from http://www.stmas.bayern.de/frauen/beruf/index.php.

Bavarian State Ministry of Employment and Social Order, the Family and Integration (n.d.). Gestaltungsfelder: Konkrete Gestaltungsfelder. Retrieved February 14, 2015, from http://www.kompetenzgewinn.bayern.de/fachkraefte/gestaltungsfelder/index.php.

Bavarian State Ministry of Employment and Social Order, the Family and Women (Ed.) (2010). Frauen in Führungspositionen ( No. 1001 0265). Würzburg. Retrieved January 27, 2015, from http://www.eff-portal.de/effNavi/content/Tools/PDF/FraueninFuehrungspositionen.pdf.

Bureau for Employers' Activities (ACT/EMP) (2015). Women in Business and Management: Gaining Momentum. Abridged Version of the Global Report. Retrieved February 11, 2015, from International Labour Office: http://www.ilo.org/wcmsp5/groups/public/---dgreports/---dcomm/--publ/documents/publication/wcms_334882.pdf.

Confederation of German Employers' Associations (BDA) (2014). Mehr Frauen in Führungspositionen. Retrieved February 11, 2015, from http://www.arbeitgeber.de/www/arbeitgeber.nsf/id/DE_Frauen_in_Fuehrungspositionen.

Deutscher, Bundestag (2015). Entwurf eines Gesetzes für die gleichberechtigte Teilhabe von Frauen und Männern an Führungspositionen in der Privatwirtschaft und im öffentlichen Dienst. Retreived on April 26, 2015 from: http://dip21.bundestag.de/dip21/btd/18/037/1803784.pdf.

Ehrenstein, C. (2013). Deutsche sind lieber gesund als erfolgreich. Retrieved January 27, 2015, from http://www.welt.de/politik/deutschland/article122049432/Deutsche-sind-lieber-gesund-als-erfolgreich.html.

European Commission (2014). What are the causes? Retrieved January 27, 2015, from http://ec.europa.eu/justice/gender-equality/gender-pay-gap/causes/index_en.htm.

Federal Ministry of Justice and Consumer Protection (2014). Förderung von Frauen in Führungspositionen: Kabinett beschließt Gesetzentwurf zur Frauenquote. Retrieved February 11, 2015, from http://www.bmjv.de/SharedDocs/Kurzmeldungen/DE/2014/20141211-Frauenquote.html?nn=3433226.

Federal Statistical Office (2014). Auf dem Weg zur Gleichstellung?: Bildung, Arbeit und Soziales - Unterschiede zwischen Frauen Männer. Retrieved February 11, 2015, from https://www.destatis.de/DE/Publikationen/Thematisch/Bevoelkerung/Querschnitt/WegzurGleichstellung5120 001149004.pdf?_blob=publicationFile.

Harter, J. K., Schmidt, F. L., \& Keyes, C. L. (2002). Well-being in the workplace and its relationship to business outcomes: A review of the Gallup studies. Flourishing: Positive psychology and the life well-lived, 2, $205-224$.

Hofmeister, H. \& Hünefeld, L. (2010). Frauen in Deutschland: Frauen in Führungspositionen. Retrieved January 27, 2015, from http://www.bpb.de/gesellschaft/gender/frauen-in-deutschland/49400/fuehrungspositionen?p=0 .

Hofstede, G. (1984): Culture's Consequences: International Differences in Work-related Values. Thousand Oaks, Sage Publications.

Holst, E., \& Kirsch, A. (2015). Executive Board and Supervisory Board Members in Germany's Large Corporations Remain Predominantly Male. In DIW Economic Bulletin.ECONOMY.POLITICS.SCIENCE. Women Executive Barometer, 5(4), pp. 35-47): DIW Berlin - German Institute for Economic Research. Retrieved January 27, 2015, from: http://www.diw.de/documents/publikationen/73/diw_01.c.495420.de/diw_econ_bull_2015-04.pdf.

Holst, E. \& Wiemer, A. (2010). Zur Unterrepräsentanz von Frauen in Spitzegremien der Wirtschaft Ursachen und Handlungsansätze. Retrieved February 14, 2015, from http://www.diw.de/documents/publikationen/73/diw_01.c.356535.de/dp1001.pdf.

Hucht, M. (2015). Frauen in Führungspositionen: 13 Jahre verschenkt. Retrieved January 27, 2015, from http://www.spiegel.de/karriere/berufsleben/frauenquote-diw-managerinnen-barometer-ueber-frauen-infuehrung-a-1014123.html. 
Bdkdemir, I., Ackermann, M., Beil, L., Croger, N., \& Mujtaba. B. G. (2015). Gender Gap in German Management Positions and Recommendations for Equality. Advances in Social Sciences Research Journal, 2(6) 64-81

International Labour Organization (2015). Geschlechtergleichheit: Frauen in Top-Positionen von Unternehmen. Neue ILO-Studie belegt den Zusammenhang zwischen Frauen in Führungspositionen und Geschäftserfolg. Retrieved February 14, 2015, from http://www.ilo.org/berlin/presseinformationen/WCMS_335702/lang-de/index.htm.

Kahle, Lynn R. (1983). A theory and a method for studying Values. In L. R. Kahle, Social Values and social change. Adaption to Life in America (pp. 43-72). New York: Praeger.

Kleinert, C. (2006). Frauen in Führungspositionen: Karriere mit Hindernissen: Kurzbeschreibung. Retrieved February 11, 2015, from http://www.iab.de/194/section.aspx/Publikation/k060606n19.

Kochanek, D. (2007). Welche Werte den Deutschen wichtig sind: Unsere repräsentative Umfrage zeigt: Am wichtigsten ist und bleibt den Deutschen die Familie. Retrieved January 27, 2015, from http://www.google.co.th/url?sa=t\&rct=j\&q=\&esrc=s\&source=web\&cd=1\&ved=0CB4QFjAA\&url=http $\% 3 A \% 2 F \%$ 2Fwww.rd-presse.de\%2Fpressemitteilungen \%2Fmagazin-readers-digest\%2Ffamilie-und-ehrlichkeit-sind-dendeutschen-amwichtigsten\%2F0707_werte_artikel.pdf\%2Fat_download\%2Ffile\&ei=MrDHVIOPNYv98AXvo4CICg\&usg=AFQjCNE PqpEdm0vecpf3s9zfQBspSxX0oA\&bvm=bv.84607526,d.dGc.

Kohaut, S. \& Müller, I. (2013). Frauen in Führungspositionen: Punktgewinn ist westdeutschen Großbetrieben. Retrieved February 11, 2015, from http://doku.iab.de/kurzber/2013/kb2313.pdf.

Mead, R. \& Andrews, T. G. (2009). International Management: Cross-Cultural Dimensions (4th edition). Wiley: UK. Mujtaba, B. G. (2014). Managerial Skills and Practices for Global Leadership. ILEAD Academy: Davie, Florida.

Ministry for Family Affairs, Senior Citizens, Women and Youth (2014). Kabinett beschließt Gesetzentwurf zur Quote. Retrieved February 11, 2015, from http://www.bmfsfj.de/BMFSFJ/gleichstellung,did=212316.html.

Peuß, C. \& Welpe, I. M. (2011). Frauen in Führungspositonen: Was Unternehmen wissen sollten. Retrieved February 14, 2015, from https://www.bwv.de/fileadmin/user_upload/BWV/Bildungspolitik/Projekte/Frauen_in_der_Assekuranz/Literat ur/Artikel_Peus_und_Welpe.pdf.

Pfahl, S., Hobler, D., \& Oerder, L. (2014). Führungspositionen: Mehr weibliche Führungskräfte in kleineren Betrieben. Kurzanalyse. Retrieved February 11, 2015, from http://www.boeckler.de/51384.htm.

Reimann, A. (2012). Quote in Norwegen: Frau am Steuer. Retrieved January 27, 2015, from http://www.spiegel.de/politik/ausland/in-norwegen-funktioniert-die-frauenquote-in-aufsichtsraeten-a831693.html.

Rettig, D., Engeser, M., \& Schmidt, K. (2013). Karriere: Wie Frauen nach oben kommen. Retrieved January 27, 2015, from http://www.wiwo.de/erfolg/beruf/karriere-wie-frauen-nach-oben-kommen/8274584.html.

Rokeach, M. (1973). The nature of human values. New York-London: Free Press Collier-Macmillan.

Runia, P., Wahl, F., Geyer, O., \& Thewißen, C. (2007). Marketing: Eine prozess- und praxisorientierte Einführung. München: Oldenbourg.

Schwartz, Shalom H. (1996). Value priorities and behavior: Applying a theory of integrated value systems. In: Seligman, C.; Olson, J. M.; Zanna, M. P. The Psychology Values: The Ontario Symposium (Vol. 8, pp. 1-24.).

Schwartz, Shalom H. (1992). Universals in the content a structure of values: Theoretical advances and empirical test in 20 countries. Advances in Experimental Social Psychology, 25, pp. 2-59.). New York: Academic Press.

Schwartz, Shalom H. (1994). Are there universal aspects in the structure and contents of human values? In: Journal of Social Issues, 50(4), pp. 19-45).

Statista GmbH (2015 b). Frauenquote in den Führungspositionen in Unternehmen in weltweit ausgewählten Ländern. Retrieved January 27, 2015, from http://de.statista.com/statistik/daten/studie/214556/umfrage/frauenquote-in-unternehmen-in-ausgewaehltenlaendern/. 